\title{
Effect of Chitosan Treatments and Vacuum Packaging on the Shelf Life of Spangled Emperor Lethrinus nebulosus Fillets Stored in Refrigerator
}

\author{
Mozhgan Karimi Rezaabad $^{1} \cdot$ Ainaz $_{K^{\prime}}$ Rodanazary $^{1} \cdot$ Seyyed Mehdi Hosseini $^{1}$
}

Received: 20 March 2017/ Accepted: 21 October 2017/Published online: 2 November 2017

(c) The Author(s) 2017. This article is an open access publication

\begin{abstract}
The effect of vacuum packaging (VP) on the quality changes of Spangled emperor (Lethrinus nebulosus) treated with or without chitosan during refrigerated storage of 12 days was investigated. Treatments included the following: control (untreated, control samples stored in air), VP (untreated, stored under vacuum packaging), FV (treated with chitosan film, stored under vacuum packaging) and CV (treated with chitosan coating stored under vacuum packaging). Chitosan coated and wrapped samples prior to VP can remarkably delay the growth of total viable count and psychrotrophilic count. Production of total viable bases nitrogen and trimethylamine for FV and CV Spangled emperor samples was significantly lower than for untreated samples at day 12 of storage. The coincidental lowered rate of increase thiobarbitoric acid and free fatty acid were obtained in Spangled emperor coated chitosan stored under vacuum packaging. Vacuum-packaged samples coated with chitosan showed significantly $(\mathrm{P}<0.05)$ lower changes in a color value than uncoated samples. Therefore, Spangled emperor treated with chitosan stored under vacuum packaging had the lowest losses in quality during refrigerated storage. In addition, there was no significant difference between coating and film in reducing bacteriological, physicochemical and color parameters.
\end{abstract}

Keywords Spangled emperor · Vacuum packaging · Chitosan $\cdot$ Coating $\cdot$ Film $\cdot$ Shelf life

Ainaz Khodanazary

khodanazary@yahoo.com

1 Department of Fisheries, Faculty of Marine Natural Resources, Khorramshahr University of Marine Science and Technology, Khorramshahr, Iran

\section{Introduction}

The Spangled emperor (Lethrinus nebulosus) is one of the valued fish species in Persian Gulf, which due to its high nutritional quality and excellent sensory properties, is preferred by the customers in the south of Iran. Because this species is consumed domestically, it is very important to extend its shelf life, which is normally quite limited when kept refrigerated.

In this case, correct methods of packaging can help to preserving food for longer time. Vacuum packaging (VP) is one of the methods of the natural preservation in order to delay the degradation and maintain the quality of the products longer [26]. VP is widely used as a supplement to ice or refrigeration to decrease the supply of oxygen to the aerobic bacteria in the flesh to extend the shelf life of product [2]. Chitosan have been used in seafood products to inhibit the growth of bacteria in stored fish in refrigerator and retarded the oxidation of unsaturated fatty acids in fish muscle before vacuum packaging $[10,19,24,33]$. Chitosan, a linear polysaccharide of randomly distributed $\beta$ (1-4)-linked D-glucosamine and $N$-acetyl-D-glucosamine, is a biocompatible polysaccharide obtained from deacetylation of chitin. Edible coating is a thin layer of edible material formed as a coating on a food, while an edible film is a preformed thin layer which once formed can be placed on or between food components [6]. In food industry, Chitosan coatings have been used successfully because of some advantages such as edibility, biodegradability, aesthetic appearance and barrier properties, being nontoxic and non-polluting, as well as carrier of foods additives (i.e.: antioxidants, antimicrobials). Therefore, these coatings can retain quality of raw, frozen and processed foods including fish items by preventing bacterial growth and delaying lipid oxidation. 
Major changes occur in proximate, microbiological, chemical and sensory composition of fish fillets during storage in the refrigerator [30]. Because the Spangled emperor is consumed domestically and exported in large quantities, it is very important to extend its shelf life of this fish during refrigerated storage. There has not been research to determine the shelf life of Lethrinus nebulosus during chilled storage. Though the shelf life of Lethrinus nebulosus could be extended by VP, VP is still questionable to ensure quality and safety of the foods. Such a limited success of VP has led to the processing of seafood and seafood products prior to packaging. Thus the aim of this study was to assess the effect of chitosan (coating and film) under VP condition on the quality of Lethrinus nebulosus fillets during refrigerated storage.

\section{Materials and Methods}

\section{Sample Preparation and Storage Condition}

Lethrinus nebulosus with an average weight of $500 \mathrm{~g}$ was caught with gill net in the Persian Gulf, Khorramshahr, Iran in July 2016. Fishes were placed in crushed ice with a fish/ ice ratio $1: 3(\mathrm{w} / \mathrm{w})$ and transported to the fish processing laboratory with $2-3 \mathrm{~h}$ after catch. They were washed with tap water and two fillets were obtained from each fish after removing the head and gutted.

\section{Preparation of Coating Solution and Chitosan-Based Edible Films}

Chitosan solution was prepared with $1 \%$ (w/v) chitosan (Sigma Chemical Co., medium molecular weight, viscosity $200-800 \mathrm{cP}$ ) in 1\% v/v acetic acid [21]. To achieve complete dispersion of chitosan, the solution was stirred at room temperature to dissolve completely. Glycerol was added at $0.75 \mathrm{~mL} / \mathrm{g}$ concentration as a plasticizer and stirred for $10 \mathrm{~min}$ [21]. All films were obtained by casting $100 \mathrm{~mL}$ film forming solution on a nonstick surface $(16 \times 27 \mathrm{~cm})$, dried at ambient temperature $\left(20^{\circ} \mathrm{C}\right)$ until a firm surface but still with adhesive properties was obtained. After evaporation the films were peeled off from the plates.

Fillet samples were randomly assigned into four treatment lots consisting of: one control lot (un-coated), second lots packaged with VP, third lots wrapped with films prior to VP, fourth lots immersed for $30 \mathrm{~s}$ in chitosan solution, then the fish fillets were removed and allowed to drain for $2 \mathrm{~h}$ at ambient temperature $\left(20^{\circ} \mathrm{C}\right)$ in order to form the edible coating. All samples were stored at $4 \pm 1{ }^{\circ} \mathrm{C}$ for 12 days. Microbiological, physicochemical, color and sensorial analyses were performed at 3-day intervals to determine the overall quality of fish.

\section{Bacteriological Analysis}

Bacteriological counts were determined by homogenizing $10 \mathrm{~g}$ sample in $90 \mathrm{~mL}$ of $0.85 \% \mathrm{NaCl}$ solution. Other decimal dilutions were prepared from this dilution and plated in the appropriate media. Total viable aerobic bacterial counts were determined by the pour plate method, using plate count agar (PCA, Merk, and Darmstadt, Germany). The inoculated plates were incubated at $37{ }^{\circ} \mathrm{C}$ for 2 days for total viable counts, and at $10{ }^{\circ} \mathrm{C}$ for 7 days for psychrotrophilic counts. All counts were expressed as $\log _{10}$ CFU/g [27].

\section{Chemical Analyses}

Determination of Total Volatile Base Nitrogen (TVB-N)

TVB-N muscle was determined according to the method proposed by Goulas and Kontominas [9]. Ten grams of meat was homogenized with $2 \mathrm{~g} \mathrm{MgO}$ and $300 \mathrm{~mL}$ distilled, and seven drops of anti-foam and some boiling stones were added. The blend was heated for 45 min until the volume of boric acid solution reached $150 \mathrm{~mL}$. Boric acid containing methyl red reagent, which initially due to its acidity was red, gradually became alkali and turned green. Finally, the solution obtained from the accumulation of distillation gases by $0.1 \mathrm{~N}$ sulfuric acid to reach the onion skin color was titrated.

\section{Determination of $\mathrm{pH}$}

The $\mathrm{pH}$ measurement was carried out using a Metrohm model $713 \mathrm{pH}$ meter. Fish muscle $(2 \mathrm{~g})$ was homogenized thoroughly with $10 \mathrm{~mL}$ of distilled water and the homogenate was subjected to $\mathrm{pH}$ determination according to the method of Masniyom et al. [17].

\section{Determination of TMA}

One hundred grams of fish muscle were deproteinized as described previously and the filtrate was collected. TMA was assayed as the picrate salt by colorimetry. One milliliter of filtrate and $3 \mathrm{~mL}$ of water were added to a test tube. Three other test tubes received 1, 2 and $3 \mathrm{~mL}$ of a standard TMA solution (concentration $=0.01 \mathrm{mg} / \mathrm{mL}$ ) and 3,2 and $1 \mathrm{~mL}$ of distilled water, respectively. The TMA stock solution was prepared by adding $1 \mathrm{~mL}$ of $\mathrm{HCl}$ to $0.682 \mathrm{~g}$ of TMA and making up to a final volume of $100 \mathrm{~mL}$ with distilled water. To prepare the TMA standard solution, $1 \mathrm{~mL}$ of the stock solution was mixed with $1 \mathrm{~mL}$ of $\mathrm{HC} 1$ and diluted to $100 \mathrm{~mL}$ with water. A 5th tube containing $4 \mathrm{~mL}$ of water was used as a blank for colorimetry. One milliliter of a $20 \%$ formaldehyde solution, $10 \mathrm{~mL}$ of 
toluene and $3 \mathrm{~mL}$ of saturated potassium carbonate solution were placed in the 5 tubes. The $20 \%$ formaldehyde solution was prepared as follows: $100 \mathrm{~g}$ of magnesium carbonate and $1 \mathrm{~L}$ of commercial formaldehyde $(40 \%)$ were shaken and filtered. One hundred milliliters of this stock solution were diluted to $200 \mathrm{~mL}$ with water. The 5 tubes were shaken vigorously for $40 \mathrm{~s} ; 8 \mathrm{~mL}$ of the toluene phase were then transferred to a tube containing $0.2 \mathrm{~g}$ of anhydrous sodium sulfate and shaken until dehydrated. Five milliliters of the dehydrated toluene phase were mixed in another tube with $5 \mathrm{~mL}$ of picric acid solution prepared by diluting $1 \mathrm{~mL}$ of a picric acid stock solution to $100 \mathrm{~mL}$ with toluene. The picric acid stock solution was prepared by dissolving $2 \mathrm{~g}$ of picric acid in $100 \mathrm{~mL}$ of toluene and spectrophotometer at a wavelength of $410 \mathrm{~nm}$ [1].

\section{Determination of Thiobarbituric Acid (TBA)}

Thiobarbituric acid (TBA) measurement was determined following the method of Siripatrawan and Noipha [32]. Ten grams of homogenized sample were added with $97.5 \mathrm{~mL}$ of distillated water and $2.5 \mathrm{~mL}$ of $4 \mathrm{~N} \mathrm{HCl}$. The mixture was heated with steam distillation. Five milliliter of distillate was added to $5 \mathrm{~mL}$ of thiobarbituric reactive reagent containing 0.02 MTBA in $90 \%$ glacial acetic acid and incubated in boiling water for $35 \mathrm{~min}$. After cooling, the absorbance of the pink solution was measured at $538 \mathrm{~nm}$ using a spectrophotometer. The constant 7.8 was used to calculate the TBA number using Eq. (1). The TBA value is expressed as $\mathrm{mg}$ malonaldehyde/kg sample:

TBA value $=7.8 \mathrm{Abs}_{538}$.

\section{Determination of Free Fatty Acid (FFA)}

The free fatty acid content was determined in the lipid extract by Woyewoda'smethod according to the Eq. (2). Results were expressed in \% of oleic acid [35]:

$\mathrm{FFA}=\frac{\mathrm{N} \times\left(\mathrm{V}_{2}-\mathrm{V}_{1}\right) \times 2.82}{\mathrm{~W}}$,

$\mathrm{N}=$ normality of $\mathrm{NaOH}, \mathrm{V}_{2}=\mathrm{mL} \mathrm{NaOH}$ for samples, $\mathrm{V}_{1}=\mathrm{mL} \mathrm{NaOH}$ for blank, $\mathrm{W}=$ weight $(\mathrm{g})$ of lipid

\section{Color Measurements}

A Minolta Chroma Meter CR400 (Minolta, Osaka, Japan) was used for color measurements. Colors were expressed as CIELab coordinates. In this system, $\mathrm{L}^{*}$ represents the color lightness on a $0-100$ point scale from black to white; $\mathrm{a}^{*}$ is the position between red $(+)$ and green $(-)$; and $\mathrm{b}^{*}$ is the position between yellow $(+)$ and blue $(-)$. The color intensity is expressed by a chroma value $\left(\mathrm{C}_{\mathrm{ab}}^{*}\right)$, while hue
$\left(\mathrm{H}_{\mathrm{ab}}^{0}\right)$ corresponds to the name of the color as found in its pure state on the spectrum. These values were calculated according to the formulae:

$\mathrm{C}_{\mathrm{ab}}^{*}=\left(\mathrm{a}^{* 2}+\mathrm{b}^{* 2}\right)^{1 / 2}$ and $\mathrm{H}_{\mathrm{ab}}^{0}=\arctan \left(\mathrm{b}^{*} / \mathrm{a}^{*}\right)$.

\section{Statistical Analysis}

All measurements were replicated three times for each lot and mean values \pm standard error were reported for each case. Analysis of variance (ANOVA), Duncan's test, with confidence intervals set for a level of significance of $\mathrm{P}<0.05$ on SPSS to evaluate the significance of differences among mean values.

\section{Results and Discussion}

\section{Bacteriological Analysis}

The initial total viable counts (TVC) and psychrotrophilic counts (PTC) bacteria of control sample were found to be $2.8 \log _{10} \mathrm{CFU} / \mathrm{g}$ and $3.93 \log _{10} \mathrm{CFU} / \mathrm{g}$, respectively, indicating a high quality of the fish fillet [31]. TVC and PTC values in all the treated samples with chitosan(coating and film) and VP did not exceed the maximal permissible limit at day 9 of the storage trial (Fig. 1a, b) while that of PTC did not achieve this count to the end of 12 days storage time in FV samples. A microbiological acceptability limit is $7 \mathrm{log}$ CFU/g for fresh water and marine species that is fit for human consumption [12]. The coated and wrapped samples prior to VP had the minimum initial amount of bacteria, might be attributed to the immediate antimicrobial effect of chitosan [13, 15, 21, 23]. Chitosan might show synergistics effect with VP on inhibition of total viable counts and psychrophilic bacteria counts in Lethrinus nebulosus.

The antimicrobial effect of chitosan has been ascribed to the presence of the positively charged on the $\mathrm{NH}_{3}{ }^{+}$group of glucosamine monomer in chitosan molecules which interact with negatively charged macromolecules on the microbial cell surface, leading to the leakage of intracellular constituents of the microorganisms, moreover, the mechanism of action of chitosan appears to be related to disruption of the lipopolysaccharide layer of the outer membrane of gram-negative bacteria [23], also to its function as a barrier against oxygen transfer [13]. This result was in agreement with Günlü and Koyun [10] who reported that sea bass treated with chitosan stored under VP had the lowest mesophilic aerobic bacteria, compared with the control and VP during refrigerated storage. Tsiligianni et al. [33] observed that samples treated with chitosan and 

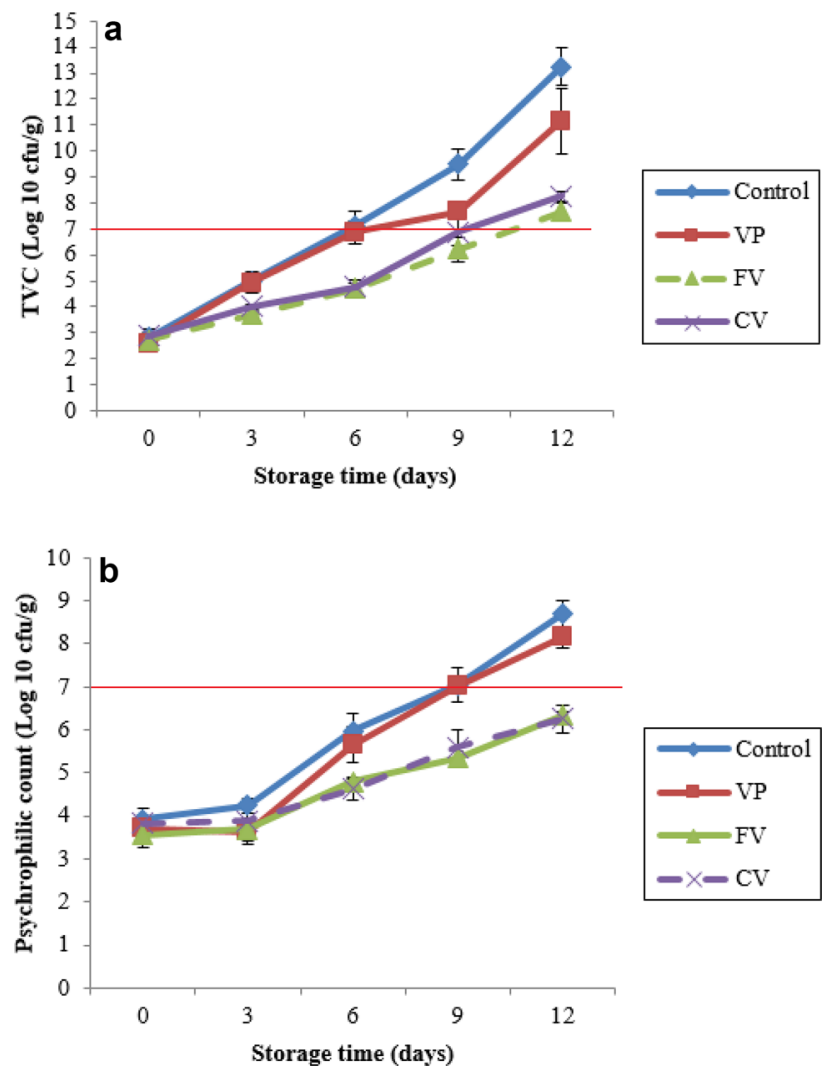

Fig. 1 Changes in total viable counts (TVC) of fish samples during refrigerated storage (a) and changes in psychrotrophilic counts (PTC) of fish samples during refrigerated storage $(\mathbf{b})$

stored under VP reduced microbial growth on swordfish. This result suggested that chitosan coated and wrapped prior to VP decreased the microbial count of the FV and $\mathrm{CV}$ during refrigerated storage.

\section{Total Volatile Base Nitrogen (TVB-N)}

Figure 2 showed the variation of TVB-N value of Spangled emperor during the storage. The initial TVB-N varied from $17 / 20 \mathrm{mg} \mathrm{N} / 100 \mathrm{~g}$ to $24.66 \mathrm{mg} \mathrm{N} / 100 \mathrm{~g}$. The TVB-N level

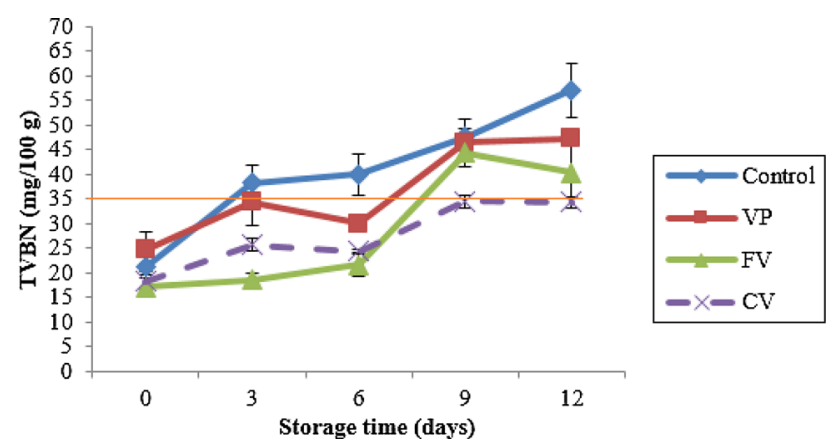

Fig. 2 Changes in TVB-N values of fish samples during refrigerated storage

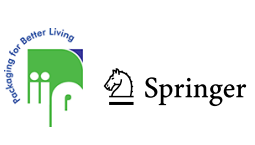

increased gradually along with the time of storage in all samples $(\mathrm{P}<0.05)$, but the increasing rate varied with treatments. TVB-N usually include calculation of trimethylamine, dimethylamine, ammonia and other volatile bases, which impart characteristic off-flavors to fish [9]. TVB-N is products of bacterial spoilage such as $S$. putrefaciens and $P$. phosphoreum, autolytic enzymes and endogenous enzymes, which used as index to assess the keeping quality and shelf life of seafood products [5].

A level of $25 \mathrm{mg} \mathrm{N} / 100 \mathrm{~g}$ muscle has been considered the highest acceptable level [14] and above $30-35 \mathrm{mg} \mathrm{N} /$ $100 \mathrm{~g}$ muscle indicate that fish is decomposed and inedible [4]. TVB-N level of CV was less $35 \mathrm{mg} \mathrm{N} / 100 \mathrm{~g}$ muscle, indicating that the fillets of fish maintained at a good quality during storage. From the result, it was found that using a coating of chitosan prior to VP resulted in a more rapidly reduced bacteria population or decreased capacity of bacteria or both [33]. At the end of the storage, TVB-N value of control was more than the others $(\mathrm{P}<0.05)$. TVB$\mathrm{N}$ value of $\mathrm{FV}$ was higher than $\mathrm{CV}$. It can be concluded, coating is more effective than film in controlling TVB-N of fillets. These effects may be attributed to the inhibitory activity on microbial growth exerted by chitosan. Edible coatings act as antimicrobial materials and affect the TVB$\mathrm{N}$ value. $[8,21,23,34]$ have announced that chitosan antimicrobial properties of coating solution is more than film structure, due to further migration of antimicrobial agents. The longer storage period of chitosan treated samples compared to untreated samples may has been due to a lower microbial counts which breakdown compounds like trimethylamine oxide (TMAO), peptides, amino acids, etc. [11], resulted in a decrease in the basic nitrogen fraction [18]. For the result, chitosan coated samples prior to VP appeared to be the most effective in TVB-N during storage.

\section{pH}

Changes in $\mathrm{pH}$ of Lethrinus nebulosus muscle during storage are presented in Fig. 3. The initial $\mathrm{pH}$ of fish samples was found between 6.96 and 7.21. During the storage time, the $\mathrm{pH}$ values increased gradually, presumably due to accumulation of basic compounds generated from both autolytic processed by endogenous enzymes and microbial enzymatic actions [20], although it could also be associated with the increase in bacterial counts especially psychrophilic bacterial counts. $\mathrm{pH}$ values of VP and/or chitosan treated (VP, CV and FV) samples were lower than control, due to its property of inhibiting the growth of bacteria, yeasts and moulds [29]. Furthermore, chitosan pretreatment prior to VP could minimize the microbial growth. 


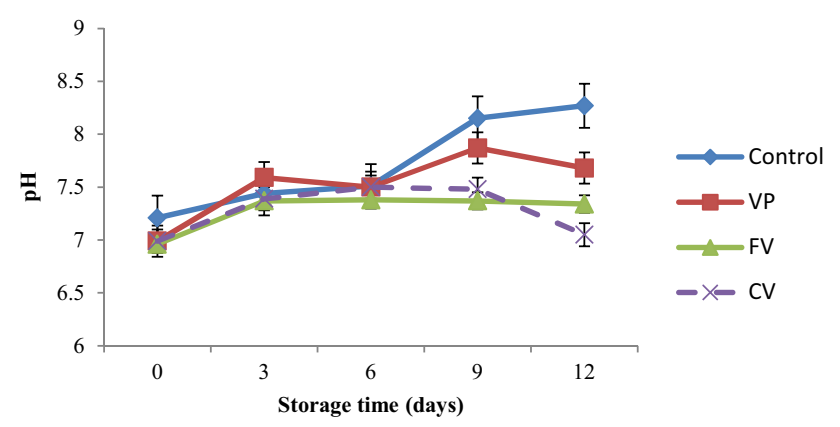

Fig. 3 Changes in $\mathrm{pH}$ values of fish samples during refrigerated storage

\section{TMA}

TMA values of fish stored in refrigerator are presented in Fig. 4. The initial TMA value of control samples was $7.25 \mathrm{mg} \mathrm{N} / 100 \mathrm{~g}$ sample which increased up to $16.27 \mathrm{mg} \mathrm{N} /$ $100 \mathrm{~g}$ sample at the end of the storage period. The present study revealed that TMA value of control Spangled emperor fillets increased during storage but chitosan-coated and chitosan-film prior to VP of Spangled emperor fillet retarded the decomposition of trimethylamine $\mathrm{N}$-oxide caused by bacterial spoilage and enzymatic activity. This reduction in TMA production when using chitosan-coated and chitosan-film samples in fish has also been reported by [10,33]. Acceptability limit of TMA for various fish species are different: sea bass (5 mg N/100 g) [16]; sardines (5-10 mg N/100 g) [22]; hake (12 mg N/100 g) and 10-15 mg N/100 g as a general limit for fish [3]. Such variations in the limit values of fish may be related to the fish species, season, initial bacterial count and storage conditions [3].

\section{Thiobarbituric Acid (TBA)}

The TBA index has been widely used as an indicator of degree of lipid oxidation. TBA values of fish stored in refrigerator are presented in Fig. 5. At 0 day, TBA value of all samples was found between 0.29 and $0.55 \mathrm{mg}$

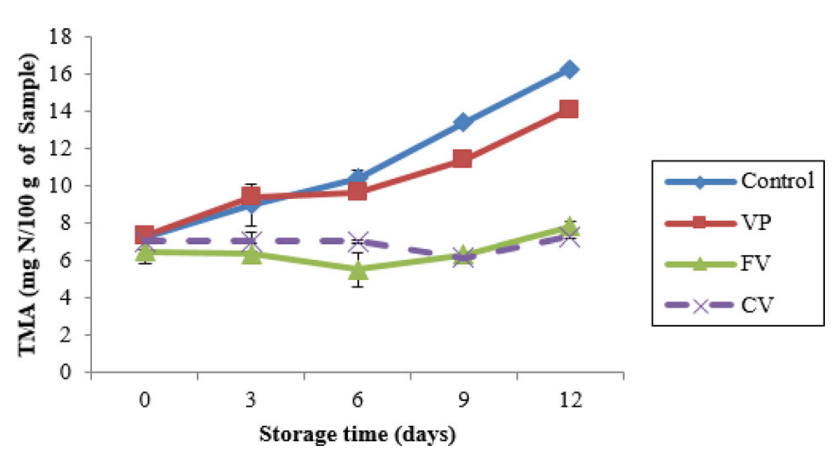

Fig. 4 Changes in TMA values of fish samples during refrigerated storage malonaldehyde $/ \mathrm{kg}$ muscle. TBA value of all samples increased when the storage time increased $(\mathrm{P}<0.05)$. The increase in TBA during storage may be attributed to the partial dehydration of fish and interacting lipids with air oxygen [14]. There is an increase in TBA values of CV and FV on day 6 and again a dip on day 9. The decline in TBA values was probably due to the reaction of malonaldehyde with various other constituents of muscle. There was no significant difference between control and treatments. This result suggested that oxidation of lipid in fish samples could be minimized by the use of chitosan probably due to the antioxidant activity as well as its low oxygen permeability characteristic of chitosan. It is reported that the antioxidant mechanism of chitosan could be by chelate action of ion metals and/or the combination with lipids of meat during storage [15]. Furthermore, chitosan coating and film have been known to be good barriers to oxygen permeation [28]. In addition, using a combination of chitosan and VP can reduce the degree of lipid oxidation in fish tissue.

TBA value of $5 \mathrm{mg}$ malonaldehyde/ $\mathrm{kg}$ muscle is an acceptable limit, while the fish may be consumed up to the level of $8 \mathrm{mg}$ malonaldehyde/kg [27]. In the current study,

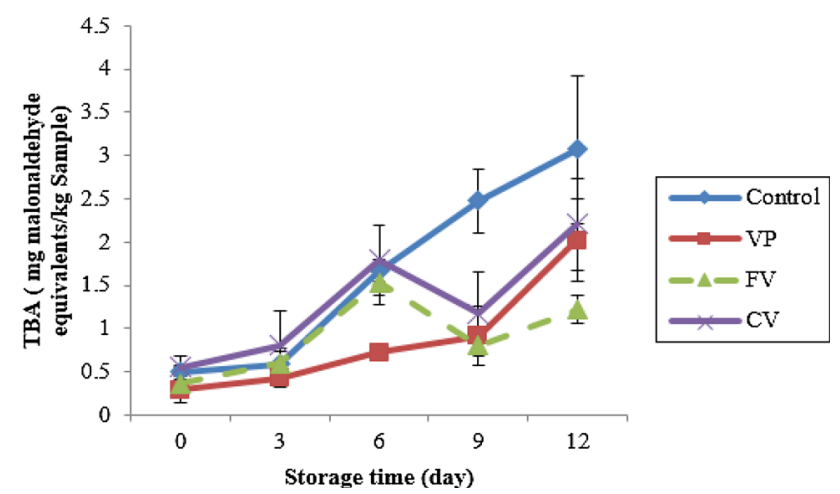

Fig. 5 Changes in TBA values of fish samples during refrigerated storage

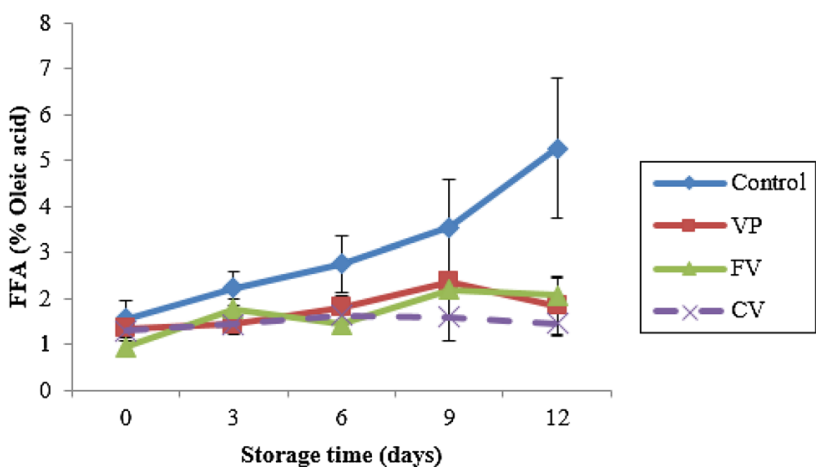

Fig. 6 Changes in FFA values of fish samples during refrigerated storage 

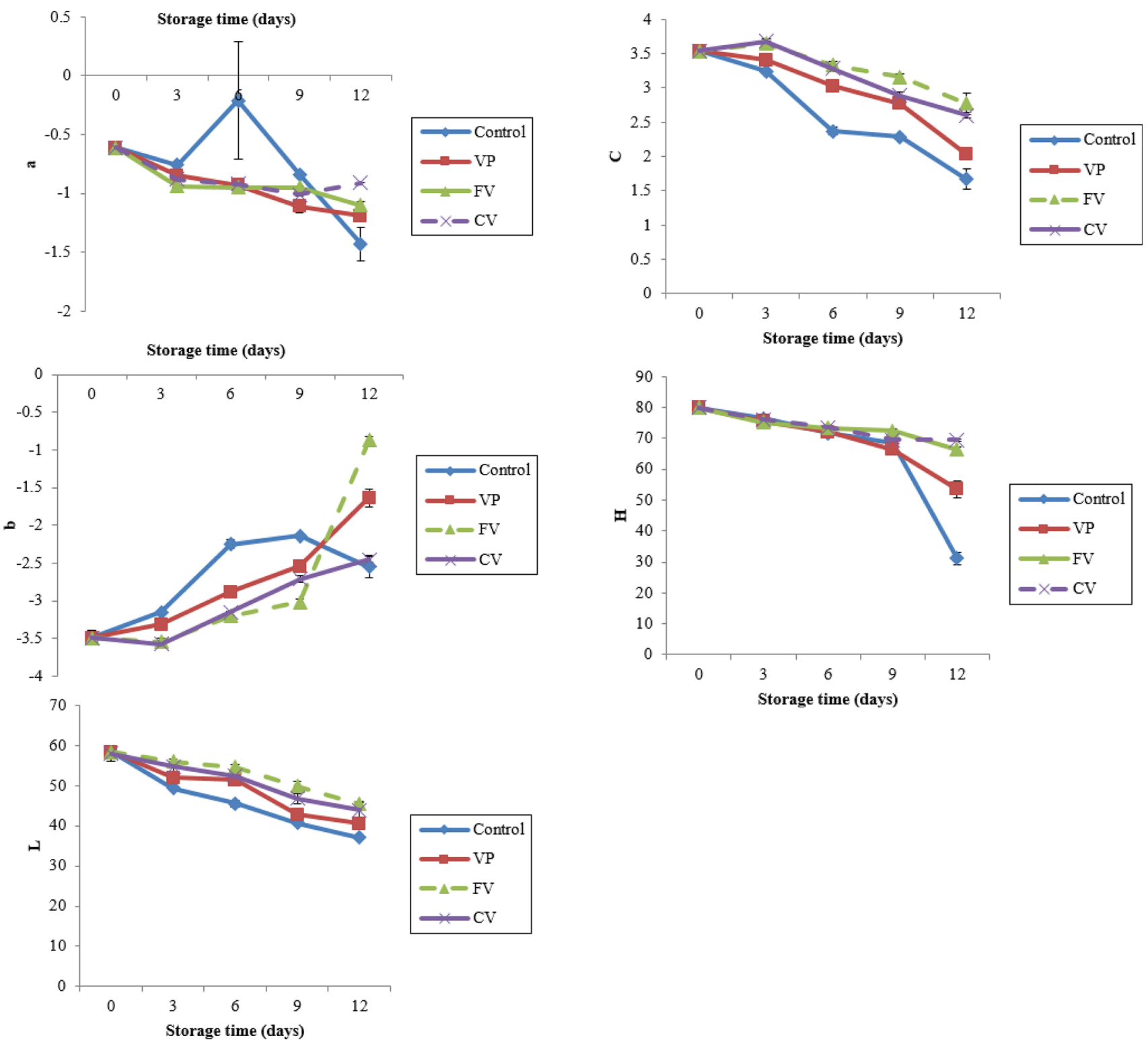

Fig. 7 Compared effect of chitosan and vacuum packaging on the changes of color of Spangled emperor during refrigerated storage

TBA value for control, VP, FV and CV was 3.07, 2.02, 1.22 and $2.21 \mathrm{mg}$ malonaldehyde/ $\mathrm{kg}$ sample, respectively, at the end of the storage. This results indicated that chitosan had important role in samples stored under VP.

\section{Free Fatty Acid (FFA)}

Both the primary and secondary oxidation products have been assessed to consider the complexity of the lipid oxidation process. The initial FFA value was from 0.95 to $1.56 \%$ of oleic acid (Fig. 6). A gradual increase in FFA formation in all samples was observed due to hydrolysis of phospholipids and triglycerides [25]. FFA value of control samples was higher than treated samples, significantly $(\mathrm{P}<0.05)$. There was no significant difference between coating and film in reducing FFA of fillets. As it was concluded from TBA values, chitosan coatings and films protect Spangled emperor fillets so would reduce production of free fatty acids. [25] was shown that FFA are known to undergo further oxidation to produce low molecular weight compounds that are responsible for off-flavor and undesirable taste of fish and fish products. This study showed that VP can reduce FFA content in samples treated with chitosan.

\section{Color}

The effect of chitosan and vacuum packaging on the changes of color of Lethrinus nebulosus during refrigerated storage are shown in Fig. 7. The appearance of food 
products is an important parameter to consumer, both from the point of view of acceptability and preference. Surface color is influenced by both muscle structure characteristics and pigment concentrations [7]. Color values including lightness $\left(\mathrm{L}^{*}\right)$ coordinate, redness $\left(\mathrm{a}^{*}\right)$ value and blueness $\left(b^{*}\right)$ value of control and sample stored under VP with and without chitosan pretreatment during storage $4{ }^{\circ} \mathrm{C}$ are shown in Fig. 7. The $a^{*}$ and $L^{*}$ value of all samples gradually decreased during the refrigerated storage. On the other hand, $\mathrm{b}^{*}$ values of Lethrinus nebulosus fillets increased as storage time increased $(\mathrm{P}<0.05)$, reflecting an evolution toward grey-blue tones. The fillets treated with chitosan film had significantly higher blueness $\left(b^{*}\right)$ value than fillets treated with chitosan coating. Coating did not affect color redness $\left(\mathrm{a}^{*}\right)$, lightness $\left(\mathrm{L}^{*}\right)$, chroma (color intensity) $\left(\mathrm{C}_{\mathrm{ab}}^{*}\right)$ and hue values of Spangled emperor fillets. The application of a coating or film during storage barely altered the lightness and $\mathrm{a}^{*}$ values $(\mathrm{P}<0.05)$ of the Spangled emperor. Chroma (color intensity) $\left(\mathrm{C}_{\mathrm{ab}}^{*}\right)$ and hue values decreased with time in storage, indicating a reduction in color intensity. Color loss in fish fillets during storage might be attributed to the lipid oxidation, oxidation of proteins with haemo groups (haemoglobin and myoglobin), non-enzymatic browning reactions between lipid oxidation products and the amine groups in proteins, and microbial spoilage [32]. The greatest rate of decrease in a* value was found in control sample. The highest increase in $\mathrm{L}^{*}$ and $\mathrm{b}^{*}$ values was also observed in control sample. From the result, degree of changes in color caused by VP could be lowered with chitosan pretreatment, especially coating fillets in chitosan of Lethrinus nebulosus. In the present experiment, however, the better color might have resulted from the well-known antioxidant property of chitosan. No previous study was encountered about the color changes of Spangled emperor fillets containing chitosan during refrigerated storage.

\section{Conclusion}

Combination of vacuum packaging and chitosan treated samples effectively retarded the TVB-N and TMA values and inhibited the growth of total viable count and psychrotrophilic count bacteria during refrigerated storage. Therefore, to extend the shelf life and delay the deterioration of fresh Spangled emperor fillets during refrigerated storage, chitosan coating prior to vacuum packaging is more appropriate. These coatings and films also showed antioxidant effect, since TBA and FFA values was lower than control samples at the end of the storage. There was no significant difference between coating and film in reducing TBA of fillets and bacterial contamination. Therefore, chitosan coating and film prior to vacuum packaging provides a type of active packaging that can be utilized as a safe preservative for fish under refrigerated storage.

Open Access This article is distributed under the terms of the Creative Commons Attribution 4.0 International License (http://crea tivecommons.org/licenses/by/4.0/), which permits unrestricted use, distribution, and reproduction in any medium, provided you give appropriate credit to the original author(s) and the source, provide a link to the Creative Commons license, and indicate if changes were made.

\section{References}

1. AOAC (1995) Association of official analytical chemists, vol 35, 15th edn. Washington DC, pp 7-9

2. Ayala MD, Santaella M, Martínez G, Periago MJ, Blanco A, Vázquez JM, Albors OL (2011) Muscle tissue structure and flesh texture in gilthead sea bream Sparus aurata L., fillets preserved by refrigeration and by vacuum packaging. Food Sci Technol 44:1098-1106

3. Connell JJ (1990) Control of fish quality. Fishing News Books, London

4. Connell JJ (1995) Control of fish quality, 4th edn. Fishing News Books Limited, London, p 245

5. Etemadian Y, Shabanpour B, Mahoonak AS, Shabani A (2012) Combination effect of phosphate and vacuum packaging on quality parameters of Rutilus frisii kutum fillets in ice. Food Res Int 45:9-16

6. Falguera V, Quintero JP, Jiménez A, Munoz JA, Ibarz A (2011) Edible films and coatings: structures, active functions and trends in their use. Trends Food Sci Technol 22:292-303

7. Gines R, Afonso JM, Arguello A, Zamorano MJ, López JL (2004) The effects of long-day photoperiod on growth, body composition and skin colour in immature gilthead sea bream (Sparus aurata L.). Aquacult Res 35:1207-1212

8. Gomez-Estaca J, Lopez de Lacey A, Lopez-Caballero ME, Gomez-Guillen MC, Montero P (2010) Biodegradable gelatinchitosan films incorporated with essential oils as antimicrobial agents for fish preservation. Food Microbiol 27:889-896

9. Goulas AE, Kontominas MG (2005) Effect of salting and smoking-method on the keeping quality of chub mackerel (Scomber japonicus). Biochemical and sensory attributes. Food Chem 93:511-520

10. Günlü A, Koyun E (2013) Effects of vacuum packaging and wrapping with chitosan-based edible film on the extension of the shelf life of sea bass (Dicentrarchus labrax) fillets in cold storage $\left(4{ }^{\circ} \mathrm{C}\right)$. Food Bioprocess Technol 6:1713-1719

11. Gram L, Huss HH (1996) Microbiological spoilage of fish and fish products. Int J Food Microbiol 33:121-137

12. ICMSF (1986) Microorganisms in foods. The international commission on microbiological specifications for foods of the international union of biological societies. Blackwell Scientific Publications, Oxford

13. Jeon YJ, Kamil JYVA, Shahidi F (2002) Chitosan as an edible invisible film for quality preservation of herring and Atlantic cod. J Agric Food Chem 50:5167-5178

14. Kilincceker O, DoganI S, Kucukoner E (2009) Effect of edible coatings on the quality of frozen fish fillets. Food Sci Technol 42:868-873

15. Lopez-Caballero ME, Gomez-Guillon MC, Perez-Mateos M, Montero P (2005) A chitosan-gelatin blend as a coating for fish patties. Food Hydrocoll 19:303-311 
16. Masniyom P, Benjakul S, Visessanguan W (2002) Shelf-life extension of refrigerated sea bass slices under modified atmosphere packaging. J Sci Food Agric 82:873-880

17. Masniyom P, Soottawat B, Visessanguan W (2005) Combination effect of phosphate and modified atmosphere on quality and shelf-life extension of refrigerated seabass slices. Food Sci Technol 38:745-756

18. Mohan CO, Ravishankar CN, Lalitha KV, Srinivasa Gopal TK (2012) Effect of chitosan edible coating on the quality of double filleted Indian oil sardine (Sardinella longiceps) during chilled storage. Food Hydrocoll 26:167-174

19. Morachis-Valdez AG, Gómez-Oliván CM, Carcía-Argueta I, Hernánedez-Navarro MD, Díaz-Bandera D, Dublán-García O (2017) Effect of chitosan edible coating on the biochemical and physical characteristics of carp fillet (Cyprinus carpio) stored at $-18{ }^{\circ} \mathrm{C}$. Int J Food Sci 2017:1-10

20. Nirmal NP, Benjakul S (2011) Retardation of quality changes of Pacific White shrimp by green tea extract treatment and modified atmosphere packaging during refrigerated storage. Int $\mathrm{J}$ Food Microbiol 149:247-253

21. Ojagh SM, Rezaei M, Razavi SH, Hosseini SMH (2010) Effect of chitosan coatings enriched with cinnamon oil on the quality of refrigerated rainbow trout. Food Chem 120:193-198

22. Ozogul F, Polat A, Ozogul Y (2004) The effects of modified atmosphere packaging and vacuum packaging on chemical, sensory and microbiological changes of sardines (Sardina pilchardus). Food Chem 85:49-57

23. Pereda M, Ponce AG, Marcovich NE, Ruseckaite RA, Martucci JF (2011) Chitosan-gelatin composites and bi-layer films with potential antimicrobial activity. Food Hydrocoll 25:1372-1381

24. Remya S, Mohan CO, Bindu J, Sivaraman GK, Venkateshwarlu G, Ravishankar CN (2016) Effect of chitosan based active packaging film on the keeping quality of chilled stored barracuda fish. J Food Sci Technol 53:685-693

25. Rostamzad H, Shabanpour B, Shabani A, Shahiri H (2011) Enhancement of the storage quality of frozen Persian sturgeon fillets by using of ascorbic acid. Int Food Res J 18:109-116
26. Sahoo J, Kumar N (2005) Quality of vacuum packaged muscle foods stored under frozen conditions: a review. J Food Sci Technol 42:209-213

27. Sallam KI (2007) Antimicrobial and antioxidant effects of sodium acetate, sodium lactate and sodium citrate in refrigerated sliced salmon. Food Control 18:566-575

28. Sathivel S, Liu Q, Huang J, Prinyawiwatkul W (2007) The influence of chitosan glazing on the quality of skinless pink salmon (Oncorhynchus gorbuscha) fillets during frozen storage. J Food Eng 83:366-373

29. Shahidi F, Arachchi JKV, Jeon Y-J (1999) Food applications of chitin and chitosans. Trends Food Sci Technol 10:37-51

30. Sharifian S, Zahipour E, Mortazavi MS, Arshadi A (2011) Quality assessment of tiger tooth croaker (Otolithes ruber) during ice storage. Int J Food Prop 14:309-318

31. Sikorski ZE, Kolakowska A, Burt JR (1990) Post harvest biochemical and microbial changes seafood. In: Sikorski ZE (ed) Resources nutritional composition and preservation. CRC Press Inc., Boca Raton, pp 55-75

32. Siripatrawan U, Noipha S (2012) Active film from chitosan incorporating green tea extract for shelf life extension of pork sausages. Food Hydrocoll 27:102-108

33. Tsiligianni M, Papaverogou E, Soultos N, Magra T, Savvaidis IN (2012) Effects of chitosan treatments on quality parameters of fresh refrigerated Swordfish (Xiphias gladius) steaks stored in air and under vacuum condition. Int J Food Microbiol 159:101-106

34. Vasconez MB, Flores SK, Campos CA, Alvarado J, Gerschenson LN (2009) Antimicrobial activity and physical properties of chitosan-tapioca starch based edible films and coatings. Food Res Int 42:762-769

35. Woywoda AD, Shaw SJ, Ke PJ, Burns BG (1986) Recommended laboratory methods for assessment of fish quality. Canadian technical report of fisheries and aquatic sciences, p 1448 